\title{
Equivalence of Islamic Financial Literation Index with Islamic Financial Inclusion Index in The Islamic Banking Sector: A Case Study of DIY Society
}

\author{
Miftakhul Khasanah \\ Universitas Muhammadiyah Yogyakarta, Yogyakarta, Indonesia \\ email: miftakhulkhasanah@umy.ac.id
}

\begin{abstract}
The purpose of this research is to find out and analyse the relationship between the Islamic financial literacy index and the Islamic financial inclusion index of the DIY community in the Islamic banking sector. The research uses descriptive quantitative methods. Data collection was carried out by distributing 663 questionnaires in the DIY province. The calculation of the index of Islamic financial literacy and inclusion was carried out by referring to the OJK calculation and Sharma method. From the results of the calculation of the Islamic financial literacy index in DIY Province, the results were $32.47 \%$ while the Islamic financial literacy index, specifically for the Islamic banking sector was $26.15 \%$. This result is much higher than the calculation of the Islamic financial literacy index conducted by OJK in 2016. Financial literacy is closely related to financial inclusion so that there needs to be conformity and continuity between both of them. Achievement of financial literacy and inclusion strategies will be more efficient if carried out together so that the achievement of public access to the financial services sector can be done more optimally and can utilise financial products and services that are suitable to achieve sustainable economic prosperity.
\end{abstract}

Keywords: Islamic finance; literacy; inclusion, Financial Services Authority

\begin{abstract}
Abstrak: Tujuan dari penelitian ini adalah untuk mengetahui dan menganalisis keterkaitan antara indeks literasi keuangan syariah dan indeks inklusi keuangan syariah masyarakat DIY pada sektor perbankan Syariah. Penelitian menggunakan metode kuantitatif deskriptif. Pengumpulan data dilakukan dengan menyebarkan kuisioner di propinsi DIY. Perhitungan indeks literasi dan inklusi keuangan syariah dilakukan dengan merujuk pada perhitungan OJK dan metode Sharma. Dari hasil perhitungan indeks literasi keuangan Syariah di Propinsi DIY didapatkan hasil sebesar 32,47\% sedangkan indeks literasi keuangan Syariah khusus untuk sektor perbankan syariah adalah 26,15\%. Hasil ini jauh lebih tinggi daripada perhitungan indeks literasi keuangan syariah yang dilakukan OJK di DIY pada tahun 2016. Pencapaian strategi literasi dan inklusi keuangan akan lebih efisien jika dilakukan secara bersama-sama sehingga pencapaian akses masyarakat ke sektor jasa keuangan dapat dilakukan dengan lebih optimal dan dapatmemanfaatkan produk dan layanan jasa keuangan yang sesuai untuk mencapai kesejahteraan keuangan yang berkelanjutan.
\end{abstract}

Kata Kunci: Keuangan Islam; literasi; inklusi, Otoritas Jasa Keuangan

Economica: Jurnal Ekonomi Islam - Volume 10, Nomor 2 (2019) 


\section{Introduction}

Financial literacy is a basic need for everyone to avoid financial problems. Financial difficulties are not just low income. Instead, financial difficulties can arise if a person does not have a knowledge base in financial management such as the use of credit/financing, investment and lack of financial planning, especially for the long-term and errors and indiscipline in managing and using loans or loans obtained. In other words, financial literacy is needed in the financial inclusion process so that someone understands their rights and obligations. Knowing financial literacy is necessary to getting a prosperous life. With the right financial management which is certainly supported by good financial literacy, the standard of living is expected to increase, this applies to every level of income, because no matter how high a person's income level, without proper management, financial security will certainly be difficult to achieve (Mendari and Kewal, 2013).

As a country that has the fourth largest population in the world, Indonesia has a lot of people who lack understanding and are not utilising financial institutions (unbankable). The level of financial literacy in developed countries is admittedly higher than in developing countries. One of the problems that have surfaced in Indonesia is the financial sector gap that is still relatively high compared to neighbouring countries. The gap in the financial sector in Indonesia is not only about affordability (inclusion), but also about comprehension (literacy).

This research on Islamic financial literacy and inclusion takes community objects in DIY because the results of a recent survey conducted by the Financial Services Authority (OJK) in 2016 stated that the DIY Islamic financial literacy index of the people was at the level of $9.45 \%$ and the Islamic financial inclusion index was $13.45 \%$. Whereas for the general (conventional) financial literacy index in the DIY community is $38.55 \%$ with the financial inclusion index reaching 76.73\% (OJK, 2016). 
From the survey conducted by OJK, the level of Islamic literacy and inclusion in communities in DIY is shallow and differs significantly from the level of literacy and inclusion in general; there is a high gap between the financial literacy index and the financial inclusion index (both Islamic and general). While in DIY Province until the end of 2016, 13 Islamic banks were operating, there are 9 Islamic Commercial Banks and 4 Islamic Business Units and by the end of 2015, the growth of Islamic banking assets in DIY reached $8 \%$ far exceeding the national average asset growth of $4.5 \%$, reaching almost twice as much as that. Therefore, there is a significant difference between the level of literacy and inclusion of Islamic finance with Islamic banking assets.

If the Islamic financial literacy index in the community increases, there will be an increase in the level of Islamic financial inclusion. If that happens to the Islamic banking sector, it will be able to increase the market share of Islamic banking to national banks. If the Islamic financial literacy index in the community increases, there will be an increase in the level of product use in the Islamic financial services industry. If the level of Islamic financial inclusion is low, but the growth of Islamic banking assets is high or vice versa then it becomes a question that needs to research. This study tries to find out and analyse the relationship between the Islamic financial literacy index and the Islamic financial inclusion index of the DIY community in the Islamic banking sector.

\section{Literature review}

\section{Islamic financial literacy}

According to OJK, financial literacy is a series of processes or activities to increase the knowledge, beliefs, and skills of consumers and the broader community so that they can manage finances well. The definition of financial literacy varies, as some of them, Lusardi and Mitchell, (2014) define financial literacy as financial knowledge and the ability to apply it (knowledge and ability). 
Meanwhile, Danes and Hira, (1987) and Chen and Volpe (1998) define financial literacy as financial management knowledge (financial literacy is money management knowledge). The Presidential Advisory Council on Financial Literacy (PACFL, 2008) in (Hung et al., 2009) defines Financial literacy: the ability to use knowledge and skills to manage financial resources effectively for a lifetime of financial well-being (financial literacy as the ability to apply knowledge and expertise to manage financial resources to achieve prosperity). Financial literacy is the level of people's basic knowledge about finance, which includes skills in managing their finances, such as getting out, spending, saving, investing, and borrowing money (credit). The level of public understanding of financial literacy will be an essential provision in any economic decision making that can increase its financial resources, and encourage access to the financial system (Lusardi and Mitchell, 2014b).

Financial literacy should have an indicator that implies that an individual must have the ability and confidence to use his financial knowledge to make financial decisions. When developing instruments to measure financial literacy, it is important to determine that not only someone knows the information but also whether he can apply it appropriately (Huston, 2010). Lusardi and Mitchell (2011), uses the concept of measuring basic financial understanding, namely calculating and understanding about interest rates and compound interest, understanding inflation, and understanding risk diversification. While on the other hand, interest or usury is not justified in Islam. Therefore, his measure cannot be expressed in measuring financial literacy for Muslims. From the above definition, it can be concluded that financial literacy is knowledge about finance and the ability to use that knowledge (applying it) in everyday life to achieve prosperity.

OECD INFE defines financial literacy as follows: "A combination of awareness, knowledge, skills, attitude, and behaviour necessary to make sound financial decisions and ultimately achieve individual well-being." Financial literacy is a combination of awareness, knowledge, attitude, and 
behaviours needed to make financial decisions that ultimately achieve individual prosperity. Taking from various definitions and meanings of Islamic financial literacy or the level of Islamic financial literacy can be defined as awareness, knowledge, attitudes, and behavior in making decisions related to various financial activities of a person, in this case, specifically regarding Islamic finance including activities philanthropy related to zakat, infaq and alms (sadaqah).

Until now, there is no proper method, method or measurement model of Islamic financial literacy level which can be used as a basis for measuring the level of Islamic financial literacy. OJK uses a method of measuring the level of Islamic financial literacy and Islamic financial inclusion which refers to the $0 \mathrm{JK}$ questionnaire model. Measurement of the level of literacy used by OJK is to measure indicators of Islamic financial literacy index, namely knowledge, skills, beliefs, attitudes, and behaviours which are of course based on Islamic aspects (Bidang Edukasi dan Perlindungan Konsumen, OJK, 2017).

These beliefs, attitudes and behaviours can be aligned with the level of one's religiosity. So, indicators of beliefs, attitudes and behaviour are based on the level of religiosity, especially those related to economic activity. Religiosity is used as a primary value based on several researches that have been formerly conducted, among others, Worthington et al., (2003), which states that religious commitment is a person's commitment to using religious values, beliefs and religious practices in daily life. Mutiara et al., (2015) state that religiosity has a positive relationship with all variables contained in the framework of Maqasid al-Shari'ah with varying levels of relationship. The strongest relationship is between religiosity (Hifzh ad-Din) and Hifzh an-Nafs (Personal Soul Development) and Hifzh al-Mal (Wealth Development) then accompanied by Hifzh al-'Aql (Intellectual Development).

Economic studies are mainly related to halal earnings, the virtue of practising virtues and piety that manifests in the practice of prayer, zakat and charity are set in the Qur'an. This is indicated by several sentences:

Economica: Jurnal Ekonomi Islam - Volume 10, Nomor 2 (2019) 
Miftakhul Khasanah

"Had the People of the Scripture believed and been righteous, We would have remitted their sins, and admitted them into the Gardens of Bliss. Had they observed the Torah and the Gospel, and what was revealed to them from their Lord, they would have consumed amply from above them, and from beneath their feet. Among them is a moderate community, but evil is what many of them are doing." (al Ma'idah: 65-66).

"A messenger who recites to you Allah's Verses, clear and distinct that he may bring those who believe and work righteousness from darkness into light. Whoever believes in Allah and acts with integrity, He will admit him into gardens beneath which rivers flow, therein to abide forever. Allah has given him an excellent provision." (At-Talaq: 11).

"And eat of the lawful and good things God has provided for you; and be conscious of God, in whom you are believers" (al Ma'idah: 88).

"Tell My servants who have believed to perform the prayers, and to give from what We have given them, secretly and publicly, before a Day comes in which there is neither trading nor friendship." (Ibrahim: 31).

Say, "Who provides for you from the heaven and the earth? And who controls the hearing and the sight? And who produces the living from the dead, and produces the dead from the living? And who governs the Order?" They will say, "Allah." Say, "Will you were not careful?". (Yunus: 31).

Say, "Have you considered the sustenance Allah hassent down for you, some of which you made unlawfully, and some lawful?" Say, "Did Allah give you permission, or do you fabricate lies and attribute them to Allah?". (Yunus: 59)

"Those who recite the Book of Allah (Al-Qur'an), and perform the prayer, and spend of what We have provided for them, secretly and publicly, expect a trade that will not fail." (Fatir: 29)

Based on the aspects of religiosity and Maqāșid al-Sharī'ah as a legal basis in Islamic economics (Rohmati, Anggraini and Widiastuti, 2018). I compiled Islamic financial literacy indicators arranged in indicators of knowledge, skills, beliefs, attitudes, and behaviours. 
Equivalence of Islamic Financial Literation Index with...

\section{Islamic financial inclusion}

Bank Indonesia (2014) defines inclusive finance as the right of everyone to have access and full services from financial institutions in a timely, convenient, informative, and affordable manner. Financial services are available to all segments of society, with special attention to the poor, productive poor, workers migrants, and residents in remote areas. According to the Reserve Bank of India (RBI) in Iskandar Umar (2017), financial inclusion is defining as a process of accessing products, and financial services needed by all people and vulnerable groups such as weaker groups and lowincome groups in particular, at affordable costs fairly and transparently.

The Global Partnership for Financial Inclusion (GPFI-CGAP) Forum in 2012 defines inclusive finance as a situation where all working-age adults have adequate access to credit, savings, payments and insurance from formal service providers. Sufficient access involves providing convenient and responsible services, at a cost that is affordable for customers and sustainable for providers, with the result that financially excluded customers use formal financial services rather than existing informal choices.

From the above definition, it can be concluded that financial inclusion is defined as the provision of access to formal financial services at affordable costs for people in low-income and vulnerable groups, who have the opportunity to gain access to financial services in the financial services industry.

Whereas Islamic financial inclusion can be defined as easy to access, affordability, ease of service procedures and utilisation or use of products and services by the public in the Islamic financial sector which includes: Islamic banking, Islamic insurance, Islamic pawnshops, Islamic Pension Funds, Islamic Financing Institutions, and Islamic Capital Markets. Islamic financial services institutions can identify and develop financial products and services that are commercially profitable while at the same time providing benefits for

Economica: Jurnal Ekonomi Islam - Volume 10, Nomor 2 (2019) 
community groups, which currently cannot utilise and access Islamic financial products and services (Singh, 2014). The term financial inclusion began to be proclaimed and became a trend after the 2008 crisis. The crisis affected groups in the bottom of the pyramid (low and irregular income, living in remote areas, disabled people, workers without legal identity documents, and suburban communities) who are generally unbanked. This group is noted to be very high outside of developed countries (Bank Indonesia, 2014).

In the 2009 G20 Pittsburgh Summit, G20 members agreed on the need to increase financial access for this group which was confirmed at the Toronto Summit in 2010, with the issuance of 9 Principles for Innovative Financial Inclusion as a guideline for the development of inclusive finance. These principles are leadership, diversity, innovation, protection, empowerment, cooperation, knowledge, proportionality, and framework.

Based on the results of research conducted by Mbutor, (2013), analysing the impact of financial inclusion on monetary policy in Nigeria in 1980-2012 shows that the growth of financial inclusion can improve the effectiveness of the monetary policy. Financial inclusion can reduce dependence on loans, credit or investment from foreign parties through increased deposits, especially the amount of public savings to reduce pressure on the foreign exchange market and create domestic exchange rate stability.

Research by Sanjaya (2016), shows that Jakarta is categorised as a province with 0.074 IFI in the year 2014. During this period, Jakarta has been occupying the highest (above 0.6), except in the year 2008 (0.544). The provinces with the IFI's value medium are Bali, Yogyakarta, and East Kalimantan. Yogyakarta was the third rank in IFI index. Umar (2017) conducted a research on Islamic financial inclusion, it shows that the province of DIY ranks second after Bangka Belitung, respectively from the year 20102015. Islamic financial with the index above 0.52 . Based on the category index levels financial inclusion then Islamic finance Inclusion Index is at a level of high index. 
Equivalence of Islamic Financial Literation Index with...

\section{Methods}

The type of research used in this study is descriptive quantitative research with survey method. A quantitative approach is a research method of statistical analysis and the data are collected in the form of numbers that can be calculated. Research with this quantitative method uses a type of descriptive analysis because it is a study that analyses problems in the research. The quantitative research method is a type of research that involves taking data statistically so that calculations and interpretations can be presented in the form of graphs, diagrams, tables, and hypothesis testing.

Data collection methods are carried out by surveying and distributing questionnaires or questionnaires to the community in DIY as respondents. The respondents of this study were DIY people in 5 districts, namely Bantul, Kulonprogo, Sleman, Gunungkidul, and Jogja City. The retrieval of informants in this study was carried out by stratified random sampling.

The number of DIY residents is 3,606,111. With details per district are as follows:

Tabel 1. The population of DIY Semester 12017

\begin{tabular}{lr}
\hline City/Regency & Number of Population \\
\hline Kulon Progo & 445.655 \\
\hline Bantul & 931.356 \\
\hline Gunung Kidul & 755.977 \\
\hline Sleman & 1.062 .861 \\
\hline Yogyakarta City & 410.262 \\
\hline
\end{tabular}

Source: Population Section of the Governance Bureau of DIY Regional Secretariat

Data were collected using tests and questionnaires. The test is used to obtain data on Islamic financial literacy while the questionnaire is used to gather data on Islamic financial inclusion.

Economica: Jurnal Ekonomi Islam - Volume 10, Nomor 2 (2019) 
Miftakhul Khasanah

Data that have been successfully collected would then be tested under validity and reliability testing. Validity Test is a statistical test used to determine the validity of a question item to measure the variables studied. In this study, the validity test was carried out using the Pearson Product Moment Correlation Test. In this test, each item would be tested for its relation with the total variable score in question. In order to make this research more thorough, an item should correlate ( $r$ ) with a total score of each variable $\geq 0.05$. Items that have $r$ count $<0.05$ would not be used in this study.

While the reliability test is a statistical test used to determine the reliability of a series of question items in their reliability to measure a variable. Reliability Test is done by Alpha Cronbach test. If the alpha value is $>0.7$, it means sufficient reliability while if alpha $>0.80$ this suggests all reliable items and all tests are internally consistent because they have strong reliability (Raisch, 2004).

Table 2. Validity and Reliability Test Results

\begin{tabular}{lllllll} 
Item & Obs & Sign & $\begin{array}{l}\text { item-test } \\
\text { correlation }\end{array}$ & $\begin{array}{l}\text { item-rest } \\
\text { correlation }\end{array}$ & $\begin{array}{l}\text { average } \\
\text { interitem } \\
\text { covariance }\end{array}$ & Alpha \\
\hline tabungan & 663 & + & 0.3387 & 0.3021 & 0.0530 & 0.9401 \\
\hline deposito & 663 & + & 0.6083 & 0.5748 & 0.0510 & 0.9381 \\
\hline giro & 663 & + & 0.5554 & 0.5203 & 0.0515 & 0.9385 \\
\hline fatwa & 663 & + & 0.6456 & 0.6171 & 0.0511 & 0.9377 \\
\hline haram & 661 & + & 0.5423 & 0.5116 & 0.0519 & 0.9386 \\
\hline transaksi & 663 & + & 0.6688 & 0.6401 & 0.0508 & 0.9375 \\
\hline akad & 663 & + & 0.6899 & 0.6620 & 0.0506 & 0.9373 \\
\hline beda & 662 & + & 0.7173 & 0.6921 & 0.0505 & 0.9371 \\
\hline akadpembiayaan & 663 & + & 0.6822 & 0.6537 & 0.0506 & 0.9374 \\
\hline nisbah & 661 & + & 0.7009 & 0.6739 & 0.0505 & 0.9372 \\
\hline hakkewajiban & 661 & + & 0.6896 & 0.6617 & 0.0506 & 0.9373 \\
\hline bedabungab & 661 & + & 0.7076 & 0.6809 & 0.0504 & 0.9371 \\
\hline hatihati & 663 & + & 0.2212 & 0.1994 & 0.0539 & 0.9403 \\
\hline
\end{tabular}


Equivalence of Islamic Financial Literation Index with...

\begin{tabular}{|c|c|c|c|c|c|c|}
\hline Item & Obs & Sign & $\begin{array}{l}\text { item-test } \\
\text { correlation }\end{array}$ & $\begin{array}{l}\text { item-rest } \\
\text { correlation }\end{array}$ & $\begin{array}{l}\text { average } \\
\text { interitem } \\
\text { covariance }\end{array}$ & Alpha \\
\hline rencanajp & 663 & + & 0.5243 & 0.4923 & 0.0520 & 0.9387 \\
\hline menyisihkan & 663 & + & 0.4311 & 0.3935 & 0.0523 & 0.9395 \\
\hline halalharam & 663 & + & 0.2216 & 0.1920 & 0.0537 & 0.9405 \\
\hline pertimbangan & 662 & + & 0.2110 & 0.1848 & 0.0538 & 0.9404 \\
\hline kebutuhan & 662 & + & 0.2365 & 0.2059 & 0.0536 & 0.9404 \\
\hline sesuai & 663 & + & 0.3140 & 0.2686 & 0.0528 & 0.9407 \\
\hline bujukan & 658 & + & 0.4786 & 0.4409 & 0.0520 & 0.9392 \\
\hline transaksi & 663 & + & 0.4873 & 0.4614 & 0.0526 & 0.9390 \\
\hline penyimpan & 663 & + & 0.3028 & 0.2771 & 0.0535 & 0.9400 \\
\hline investasi & 663 & + & 0.5663 & 0.5358 & 0.0517 & 0.9384 \\
\hline keuanganse & 663 & + & 0.6149 & 0.5910 & 0.0518 & 0.9381 \\
\hline mitigasi & 663 & + & 0.6117 & 0.5839 & 0.0515 & 0.9381 \\
\hline jaminan & 663 & + & 0.5656 & 0.5336 & 0.0516 & 0.9384 \\
\hline biaya & 663 & + & 0.5333 & 0.4974 & 0.0516 & 0.9387 \\
\hline rasaaman & 663 & + & 0.4264 & 0.4045 & 0.0531 & 0.9394 \\
\hline hemat & 663 & + & 0.6245 & 0.5997 & 0.0517 & 0.9380 \\
\hline usaha & 662 & + & 0.6033 & 0.5747 & 0.0515 & 0.9381 \\
\hline keuntungan & 663 & + & 0.5002 & 0.4634 & 0.0518 & 0.9390 \\
\hline darurat & 663 & + & 0.3753 & 0.3442 & 0.0530 & 0.9397 \\
\hline risiko & 663 & + & 0.3815 & 0.3371 & 0.0524 & 0.9401 \\
\hline bedaakadb & 661 & + & 0.5752 & 0.5407 & 0.0513 & 0.9384 \\
\hline menentukan & 659 & + & 0.5413 & 0.5062 & 0.0516 & 0.9386 \\
\hline keterampilan & 661 & + & 0.5629 & 0.5299 & 0.0515 & 0.9384 \\
\hline keyakinan & 663 & + & 0.5255 & 0.4924 & 0.0519 & 0.9387 \\
\hline kompetitif & 662 & + & 0.6524 & 0.6218 & 0.0508 & 0.9377 \\
\hline banyakproduk & 660 & + & 0.5901 & 0.5564 & 0.0512 & 0.9382 \\
\hline sistem & 660 & + & 0.6889 & 0.6610 & 0.0506 & 0.9373 \\
\hline pelayanan & 659 & + & 0.6726 & 0.6439 & 0.0507 & 0.9375 \\
\hline pilihbs & 660 & + & 0.5426 & 0.5062 & 0.0515 & 0.9387 \\
\hline Test scale & & & & & 0.0518 & 0.9400 \\
\hline
\end{tabular}

Economica: Jurnal Ekonomi Islam - Volume 10, Nomor 2 (2019) 
Furthermore, from the results of the validity and reliability test, the data that passed the bias test were used to calculate the level of Islamic financial literacy index and the level of Islamic financial inclusion index.

This study took a sample of 135 respondents per district and they were expected to represent the population. The reason of taking 135 informants per area was based on the opinion of Hair Jr et al., (2015) which stated that informants as many as 100-200 people were enough to represent a study. The total respondents were 675 respondents. The number of questionnaire that fulfils the requirements for processing was only 663 . In this study, tests and questionnaires contain questions that are closed. Each respondent is required to choose answer between "Yes" or "No".

The calculation of the Islamic financial literacy index and the Islamic financial inclusion index was carried out by distributing questionnaires in 5 districts in DIY Province, namely Bantul, Gunung Kidul, Sleman, Kulonprogo and Yogyakarta Municipality. Questionnaires are distributed directly and online.

\section{Result and discussion}

\section{Islamic literacy index}

Financial Literacy according to OJK includes five indicators of knowledge, skills, beliefs, attitudes, and behaviour. The measurement of the Islamic Financial Literacy Index would be based on the five things above. The questionnaire distributed refers to the questionnaire compiled by the OJK based on SNLIK 2016 and OECD/INFE Toolkit for Measuring Financial Literacy, and Financial Inclusion carried out by the Organization for Economic Co-operation and Development (OECD), with the addition and modification of the Islamic aspects. The questionnaire was tested by testing Validity and Reliability. This study uses the STATA program. Test Validity using Pearson Correlation and test Reliability was tested with Cronbach Alpha. The technical 
measurement of the financial literacy index is the result of a comparison of the number of people who have a good literacy level with the total number of respondents in each indicator.

According to the $\mathrm{OJK}$, the level of financial literacy of the Indonesian population is divided into four parts. Well literate (21.84\%), is to have knowledge and beliefs about financial service institutions and financial service products, including features, benefits and risks, rights and obligations related to financial products and services, and to have skills in using financial products and services. Sufficient literate (75.69\%), has knowledge and beliefs about financial services institutions and financial products and services, including features, benefits and risks, rights and obligations related to financial products and services. Less literate (2.06\%), only knows financial service institutions, financial products, and services. Not literate $(0.41 \%)$, lacks knowledge and confidence in financial service institutions and financial products and services, and does not have the skills in using financial products and services.

As an illustration of understanding in general, someone who is financially literate or has a high level of personal financial literacy is accustomed to and understands how to manage personal finance and is usually indicated by how much the person interacts with banking. An easy example is the person is used to setting aside (saving) from the income received per month. But it is undeniable that the level of financial literacy is directly proportional to the economic level of the community in a country. If the per capita income of the population is large, they will have funds to save, so, naturally, the level of personal financial literacy tends to be directly proportional to the income per capita of a country.

\section{Calculation of Islamic inclusion index}

This study adopted the measurement method of Index of Financial Inclusion (IFI) used by Sarma (2015). This method is used because it provides 
a comprehensive, robust and comparable measurement method between regions. The conceptual framework of IFI is general, making it possible to enter various dimensions, depending on data availability. This method can be used to measure financial inclusion at different time points and different levels of economic and regional aggregation (village, province, state, and country)

In detail, the first step is to determine the value of each dimension (Di) using the following formula:

1. Dimensions of Accessibility (D1) Measuring the penetration of Islamic finance in the community (Sarma, 2015).

Calculated by the formula:

$$
\mathrm{D}_{1}=\frac{\text { total deposit funding }(\text { year }-\mathrm{t})}{\text { total pupulation }(\text { year }-\mathrm{t})} \times 1000
$$

According to Sarma's theory (2015), for this accessibility dimension which is a dividing factor does not need the total amount of deposit funding (DPK). The data used as a dividing factor can be in the form of data on the number of savings accounts, deposits or demand deposits based on the customer database (if one person has 2, 3 or 4 accounts, then only one account is calculated. Sarma (2015), uses data on the total amount of deposit funding (DPK) in his research because data on the number of accounts (deposits) is not available.

In this study, the Accessibility dimension was calculated by the following formula:

$$
\begin{aligned}
D_{1} & =\frac{5,111,885,623.75}{3762200} \times 1000 \\
& =1.358 .749,04
\end{aligned}
$$


2. Dimensions of Availability (D2) measuring the ability to use formal Islamic financial services by the community (Sarma, 2015).

Calculated by the formula:

$D_{2}=\frac{\text { the number of bank branches }(\text { year }-t)+\text { the number of ATMs }(\text { year }-t)}{\text { total population }(\text { year }-t)} \times 1000$

According to Sarma (2015), in this availability index, the dividing factor used is the data of the number of bank branches and the number of ATMs per 100,000 adults to measure the dimensions of availability. Two indices are calculated separately for the number of bank branches and the number of ATMs. Then, these two indices are divided based on a weighted average that uses a comparison of two to three (2/3) to index the number of bank branches and $1 / 3$ for the index of the number of ATMs.

In this study, researchers only used data on the number of Islamic bank branch offices because data on the number of ATMs was not available. Referring to (Umar, 2017), the dimensions of availability are represented by the number of bank outlets per 1000 population and the number of ATMs per 1000 population with the following dimensional calculation of availability:

$D_{2}=\frac{\text { the number of bank branches }+ \text { the number of BPRS branches }}{\text { total population }} \times 1000$

$\mathrm{D}_{2}=\frac{60+12}{3.762 .200} \times 1000$

$\mathrm{D}_{2}=0.019137739$

3. Dimensions of Usage (D3) measure the extent to which the use of Islamic banking financial services in meeting the needs of the community, including the form of deposits and Islamic financing (Sarma, 2015).

Economica: Jurnal Ekonomi Islam - Volume 10, Nomor 2 (2019) 
The formula calculates the ratio of total deposit funding (DPK) + Islamic financing (Islamic Commercial Banks, Business Units and Islamic People's Financing Banks) to Gross Regional Domestic Product (GRDP) (in billions of rupiahs):

$$
\mathrm{D}_{3}=\frac{\text { Total deposit funding }(\text { year }-\mathrm{t})+\text { total financing Sharia }(\text { year }-\mathrm{t})}{\text { Gross Regional Domestic Product }(\text { PDRB })} \times 1000
$$

The usage of an inclusive banking system in this dimension of usage can be in various forms such as credit, deposits, payments, remittances, transfers, and others. Thus, the dimensions of usage must include steps in all these different forms of utilization. However, data regarding payments, remittances, and transfers are not yet widely available or incomplete. Therefore, in combining the dimensions of usage in this index, Sarma (2015), only considers the two basic services of the banking system, credit and deposits which are embodied in the volume of credit data for the private sector and savings mobilized from the private sector as a proportion of the country's GDP ( GRDP) to measure this dimension.

By Sarma's method (2015), the calculation of usage dimensions (D3) is as follows:

$$
\begin{aligned}
& D_{3}=\frac{\text { Rp. } 5,111,885,623.75+\text { Rp. 3,603,546,107.26 }}{3.762 .200} \times 1000 \\
& D_{3}=\frac{\text { Rp.8,715,431,731.01 }}{3.762 .200} \times 1000 \\
& D_{3}=\text { Rp. } 94.42
\end{aligned}
$$

1. After all, the values of the dimensions of penetration, availability and usage of banking services have been measured, the next step is to calculate the inclusion index values in each dimension. 
Calculation of inclusion index values for each dimension (di) using the following formula:

$$
\mathrm{d}_{\mathrm{i}}=\mathrm{W}_{\mathrm{i}} \frac{\mathrm{Di}-\mathrm{mi}}{\mathrm{Mi}-\mathrm{mi}}
$$

Where:

$\mathrm{Wi}$ is the weight attached to dimension $\mathrm{i}$;

Di is the actual value of dimension $\mathrm{i}$;

$\mathrm{mi}$ is the lowest limit of dimension value $\mathrm{i}$;

and Mi is the highest limit of dimension values $i$

In this study, the weight attached to all dimensions is the same value (wi =1). By referring to the Sarma method, this study assumes that all dimensions have the same priority so that the value weight is wi $=1$ for all $\mathrm{i}$. Dimensional values that approach wi show the area with the highest achievement in all dimensions. Empirically, observations of the lowest minimum and highest maximum limits are observed. Mi points represent the maximum value of available data which is the maximum limit for each dimension, while mi represents the lowest limit.

The calculation results for each inclusion index value for each dimension (di) are as follows:

Table 3. Inclusion Dimension Index Value

\begin{tabular}{ll}
\hline Inclusion Dimension Index Value & Index Value for each dimension \\
\hline $\mathrm{d}_{1}$ & 0.082592 \\
\hline $\mathrm{d}_{2}$ & 0.564187 \\
\hline $\mathrm{d}_{3}$ & 0.317543 \\
\hline
\end{tabular}

Economica: Jurnal Ekonomi Islam - Volume 10, Nomor 2 (2019) 
Miftakhul Khasanah

2. The second step is to determine the values of $\mathrm{X} 1$ and $\mathrm{X} 2$ by using the formula below:

$$
\begin{aligned}
& \mathrm{X}_{1}=\frac{\sqrt{d_{1}^{2}+d_{2}^{2}+d_{3}^{2}}}{\sqrt{w_{1}^{2}+w_{2}^{2}}+w_{3}^{2}} \\
& \mathrm{X}_{2}=\frac{\sqrt{\left(w_{1-d_{1}}\right)^{2}+\left(w_{2}-d_{2}\right)^{2}+\left(w_{3}-d_{2}\right)^{2}}}{\sqrt{w_{1}^{2}+w_{2}^{2}}+w_{3}^{2}}
\end{aligned}
$$

Assuming that the wi value is 1 for all dimensions, the values of $\mathrm{X} 1$ and $\mathrm{X} 2$ are as follows:

$$
\begin{aligned}
& X_{1}=\frac{\sqrt{0.652657414}}{\sqrt{1.732050808}} \\
& X_{1}=0.376811933 \\
& X_{2}=\frac{\sqrt{1.223649367}}{\sqrt{1.732050808}} \\
& X_{2}=0.706474291
\end{aligned}
$$

3. The third step is to determine the IFI value as a simple average value of $\mathrm{X} 1$ and $\mathrm{X} 2$ with the following formula:

$$
\mathrm{IFI}=\frac{1}{2}\left[\mathrm{X}_{1}+\mathrm{X}_{2}\right]
$$

With the calculation method of Index Financial Inclusion (IFI), the value of the Index Financial Inclusion (IFI) is as follows:

$$
\begin{aligned}
\text { IFI } & =\frac{1}{2}[0.376811933+0.706474291] \\
& =0.541643 \\
& =0.542
\end{aligned}
$$


Equivalence of Islamic Financial Literation Index with...

\section{Analysis of index of Islamic financial literacy}

From the calculation index of Islamic financial literacy in the Province of DIY, the results were $32.47 \%$. This result is much higher than the calculation of the level of Islamic financial literacy conducted by OJK in 2016, which was 9.45\% (OJK, 2016). From the survey results, it can be seen that the understanding of DIY people towards transactions containing usury has been quite high, this can be seen from the percentage of people who understand Riba, the MUI fatwa regarding the illegitimacy of bank interest and transactions containing usury exceeding $60 \% .54 .61 \%$ of respondents know the difference between bank interest and profit-sharing system. It's just that the knowledge and understanding of the people of DIY about the contracts used in Islamic banking both in funding products and Islamic financing products on average only $40 \%$ understand and know.

The ability to calculate the profit-sharing ratio can be seen in the skills indicator, which is $29.9 \%$. But at the point of 'using banking services because of the system of profit-sharing given feels that they get justice,' there are $56.51 \%$ who answered 'YES 'which means agreeing that the profit-sharing is fairer than the interest system. The results of the calculation of the level of Islamic financial literacy index in DIY Province in the Islamic banking sector were $26.15 \%$. While nationally based on the results of the FSA calculation, the Islamic financial literacy index in the Islamic banking sector is only $6.63 \%$.

According to Chen and Volpe (1998), the level of financial literacy index is divided into three categories. $0 \%-<60 \%$ indicates that individuals have a low level of financial literacy, $60 \%-79 \%$ indicates that individuals have moderate levels of financial literacy. $>80 \%$ indicates that individuals have a high level of financial literacy. When referring to the literacy level category according to Chen and Volpe (1998), with the index of Islamic financial literacy of $32.47 \%$ and the level of literacy in the Islamic banking sector of $26.15 \%$, the level of Islamic financial literacy in the DIY community is still very low, this has

Economica: Jurnal Ekonomi Islam - Volume 10, Nomor 2 (2019) 
become a quite tricky task for policymakers related to Islamic banking activities.

In general, it can be seen that the real conditions that occur in Indonesia are that with relatively low levels of financial literacy and with the level of poverty that is still relatively high but inversely proportional to the growth of the Islamic banking industry that has shown progress. This means that the presence of Islamic banking which should be a trigger in the movement of Islamic economics, so far only serves a community that is feasible and bankable, and relatively unable to reach the poor who are the majority of Muslims (Setiawati, 2015).

In this case, it can also be understood that the level of public understanding of Islamic banking still lacks so that the performance of Islamic banking regarding promotion and socialisation must be increased again. Community understanding of Islamic banking will also affect the level of use and public access to Islamic banks. The higher the community's understanding and knowledge, the higher the percentage of the possible use of services in Islamic banking.

\section{Analysis of Islamic financial inclusion levels}

An inclusive financial system must have as many users as possible. Therefore, an inclusive financial system must reach out widely among users. The proportion of the population that has a bank account is a measure to calculate the penetration/use of banking services. In addition to banking penetration, another measurement in an inclusive financial system is the availability of banking services. This measurement describes the range of banking services so that people can access financial services wherever they are (Steelyana, 2013).

In 2010-2015, the average number of Islamic banks to serve every 100,000 population in Indonesia was 0.06 units, or in other words, 5 units are available to serve 10 million people. This amount is, of course, a very minimal 
amount related to the availability of Islamic banking services in the region. Of the 33 provinces that exist, the Special Region of Yogyakarta Province occupies the top level of availability of Islamic banking services compared to other provinces, reaching an average of 0.30 units per 100,000 population or 3 units per 1 million population (Umar, 2017).

Based on the results of the calculation of the Islamic Financial Inclusion Index in 2018 by referring to Sarma's calculation method (2015), DIY Province has a level of Islamic financial inclusion index of $0.541 \%$. Research conducted by Umar (2017), in 2015 the province's Islamic financial inclusion index of the province amounted to $0.562 \%$, this means that there has been a decline in the level of Islamic financial inclusion index in DIY.

Research conducted by Iskandar Umar, (2017) also uses the Sarma calculation method, in which the calculation of the Islamic financial inclusion index refers to the calculation of three-dimensional values, namely the dimensions of penetration, availability, and use of banking services. One indicator of the availability of banking services (availability) is the number of outlets both offices, branch offices, ATMs, branchless banking etc.

In 2017 the number of Islamic Bank and BPRS branch offices in DIY province decreased to only 72 offices, while in 2015 there were 75 branch offices. The decrease in the number of offices certainly affects the level of financial inclusion index in DIY, especially regarding availability. According to Sarma (2008), the Financial Inclusion category is divided into 3 categories. 0.5 $<$ IFI $\leq 1$ - High level of financial inclusion, $0.3 \leq$ IFI $<0.5$ - Level of intermediate financial inclusion, $0 \leq \mathrm{IFI}<0.3$ - Low level of financial inclusion. If based on the category of financial inclusion index level according to Sarma (2008), the Islamic financial inclusion index in DIY is high, which is $0.541 \%$.

When referring to the calculation method performed by OJK, the financial inclusion index is calculated by comparing the number of people using financial products and services with the total number of respondents in each 
cluster. From the results of calculations according to the OJK calculation method, the level of public Islamic financial inclusion index in the province of DIY was 57.4\%. While the level of Islamic financial inclusion in the DIY province based on the OJK in 2016 was 13.5\%, a significant difference was seen.

This difference can be influenced by the number of respondents, geographical areas, and various communities wherein this study respondent used were 663 respondents randomly in four districts (Bantul, Sleman, Gunungkidul and Kulonprogo) and 1 municipality, Yogyakarta Regency). A two-year difference can also affect an increase in three dimensions (dimensions of penetration, availability and use of banking services that affect the level of Islamic financial inclusion index).

\section{Analysis between Islamic financial literacy index and Islamic financial inclusion index}

The value of the Islamic financial literacy index in DIY is $32.47 \%$ while the value of the Islamic financial inclusion index is $57.46 \%$, it can be seen that the value of the Islamic financial inclusion index is higher than the index value of Islamic financial literacy. Financial literacy is needed in the financial inclusion process so that someone understands their rights and obligations, therefore the literacy index level should be directly proportional to the level of financial inclusion index to balance rights and obligations. Based on the survey we conducted, the purpose of using savings by respondents was various, one of which was to pay payroll salaries (salary receipts through accounts determined by the company), and the second was to make financing at the Islamic Bank, so they had to open a savings account at the Islamic bank (Razak etal., 2017).

Viewed from the characteristics of respondents, the average respondent has income of IDR 1,000,000.00 - IDR 3,000,000.00 with respondents who have $50 \%$ higher income than that, so, naturally, that they need a bank account 
to save their funds, is associated with the selection of Islamic banks, almost $60 \%$ of respondents thought that bank interest was haram (forbidden in Islam). So, they prefer Islamic banks as an alternative place to save funds. It can be concluded that the confidence indicator dominates in this case, it can be seen from the financial literacy index based on the confidence indicator which is $74.66 \%$.

\section{Conclusion}

From the calculation of the level of Islamic financial literacy in the Province of DIY, the results were $32.47 \%$ (2018). This result is much higher than the calculation of the level of Islamic financial literacy index conducted by OJK in 2016, which was $9.45 \%$. The results of the calculation of the level of Islamic financial literacy index in DIY Province in the Islamic banking sector were $26.15 \%$. While nationally based on the results of the 0JK calculation, the Islamic financial literacy index in the Islamic banking sector is only $6.63 \%$. The results show that over two years, there has been an increase in the Islamic financial literacy index of the people in the Province of DIY. Referring to the Index of financial literacy category according to Chen and Volpe (1998), with the index of Islamic financial literacy of $32.47 \%$ and the level of literacy in the Islamic banking sector of $26.15 \%$, the index of Islamic financial literacy in the DIY community is still shallow.

Based on the results of the calculation of the Islamic Financial Inclusion Index in 2018 by referring to Sarma's calculation method (2015). DIY Province has a level of Islamic financial inclusion index of $0.541 \%$. Research conducted by (Iskandar Umar, 2017), in 2015 the province's Islamic financial inclusion index of the province amounted to $0.562 \%$, this means that there has been a decline in the level of Islamic financial inclusion index in DIY. From the results of calculations according to the OJK calculation method, the level of public Islamic financial inclusion index in the province of DIY was 57.4\%. While the level of Islamic financial inclusion in the DIY province based on the 
OJK in 2016 was 13.5\%, a significant difference was seen. This might be due to differences in the calculation method between the OJK and the Sharma method.

Islamic financial literacy index value in DIY is $32.47 \%$ while the value of Islamic financial inclusion index is $57.46 \%$, it can be seen that the value of Islamic financial inclusion index is higher than the index value of Islamic financial literacy. Whereas financial literacy is needed in the financial inclusion process so that someone understands their rights and obligations, therefore the literacy index level should be directly proportional to the level of financial inclusion index to balance rights and obligations. One of which is for payroll salaries (salary receipts through accounts determined by the company), so they inevitably have to have a savings account and the second is to make financing at the Islamic Bank, so they have to open a savings account at the Islamic bank. It can be concluded that the confidence indicator dominates in this case, it can be seen from the financial literacy index based on the confidence indicator which is $74.66 \%$.

\section{References}

Bank Indonesia (2014) Booklet Financial Inclusion. Jakarta, Indonesia.

Bidang Edukasi dan Perlindungan Konsumen, O. (2017) 'Strategi Nasional Literasi Keuangan Indonesia (Revisit 2017)', in Strategi Nasional Literasi Keuangan Indonesia (Revisit 2017). OJK. Available at: https://www.ojk.go.id/id/berita-dan-

kegiatan/publikasi/Documents/Pages/Strategi-Nasional-LiterasiKeuangan-Indonesia-(Revisit-2017)-/SNLKI\%20(Revisit\%202017).pdf.

Chen, H. and Volpe, R. P. (1998) 'An analysis of personal financial literacy among college students', Financial Services Review, 7(2), pp. 107-128. doi: https://doi.org/10.1016/S1057-0810(99)80006-7.

Danes, S. and Hira, T. (1987) 'Money Management Knowledge of College Students', Journal of Student Financial Aid, 17(1). Available at: https://publications.nasfaa.org/jsfa/vol17/iss1/1. 
Hair Jr, J. F. et al. (2015) The Essentials of Business Research Methods. Taylor \& Franchis Ltd. Available at: https://www.bookdepository.com/TheEssentials-of-Business-Research-Methods-Joe-F.-

Hair/9780765646132?redirected=true\&utm_medium=Google\&utm_ca mpaign=Base5\&utm_source=ID\&utm_content=The-Essentials-of-

Business-Research-

Methods\&selectCurrency=IDR\&w=AFLYAU9S6HRMJ7A803B0\&pdg=pl a-309308959119:kwd-309308959119:cmp-806661807:adg44557562067:crv-191443663907:pid-9780765646132:devc\&gclid=EAIaIQobChMIpv3RpdGf4AIVmw4rCh1JIQSuEAYYASABEgJXN _D_BwE (Accessed: 3 February 2019).

Hung, A., Parker, A. M. and Yoong, J. (2009) Defining and Measuring Financial Literacy. SSRN Scholarly Paper ID 1498674. Rochester, NY: Social Science Research Network. Available at: https://papers.ssrn.com/abstract=1498674 (Accessed: 3 February 2019).

Huston, S. J. (2010) 'Measuring Financial Literacy', Journal of Consumer Affairs, 44(2), pp. 296-316. doi: 10.1111/j.1745-6606.2010.01170.x.

Lusardi, A. and Mitchell, O. S. (2011) 'Financial literacy around the world: an overview', Journal of Pension Economics and Finance, 10(04), pp. 497508. doi: $10.1017 /$ S1474747211000448.

Lusardi, A. and Mitchell, O. S. (2014a) 'The Economic Importance of Financial Literacy: Theory and Evidence', Journal of Economic Literature, 52(1), pp. 5-44. doi: 10.1257/jel.52.1.5.

Lusardi, A. and Mitchell, O. S. (2014b) 'The Economic Importance of Financial Literacy: Theory and Evidence', Journal of Economic Literature, 52(1), pp. 5-44. doi: 10.1257/jel.52.1.5.

Mbutor, 0. (2013) 'The impact of financial inclusion on monetary policy in Nigeria', Journal of Economics and International Finance, 5(8), pp. 318326. doi: 10.5897/JEIF2013.0541.

Mendari, A. S. and Kewal, S. S. (2013) 'Tingkat Literasi Keuangan Di Kalangan Mahasiswa Stie Musi', Jurnal Economia, 9, p. 11.

Mutiara Sadewa, M., Arif Budiman, M. and Mairijani, M. (2015) 'Hubungan Antara Religiusitas Dan KEsejahteraan Pada Masyarakat Banjar,

Economica: Jurnal Ekonomi Islam - Volume 10, Nomor 2 (2019) 
Kalimantan Selatan', AT - TARADHI Jurnal Studi Ekonomi, Volume 6(No 2), p. hal.207-218.

OJK, (first) (2016) 'Buku Statistik OJK', in Survei Nasional Literasi dan Inklusi Keuangan 2016. Available at: https://www.ojk.go.id/id/berita-dankegiatan/siaran-pers/Documents/Pages/Siaran-Pers-OJK-Indeks-

Literasi-dan-Inklusi-Keuangan-

Meningkat/17.01.23\%20Tayangan\%20\%20Presscon\%20\%20nett.co mpressed.pdf.

Raisch, S. (2004) Dynamic Strategic Analysis: Demystifying simple success strategies. Deutscher Universitätsverlag. Available at: https://www.springer.com/gb/book/9783824482498 (Accessed: 3 February 2019).

Razak, A. A. et al. (2017) 'The Role of Ar-Rahn in Enhancing Financial Inclusion: A Structural Equation Modeling Approach', Jurnal Pengurusan (UKM Journal of Management), 50(0). Available at: http://ejournal.ukm.my/pengurusan/article/view/14279 (Accessed: 3 February 2019).

Rohmati, D., Anggraini, R. and Widiastuti, T. (2018) 'Maqāșid al-Sharī'ah sebagai Landasan Dasar Ekonomi Islam', Economica: Jurnal Ekonomi Islam, 9(2), p. 295. doi: 10.21580/economica.2018.9.2.2051.

Sanjaya, I. M. (2016) 'Inklusi Keuangan Dan Pertumbuhan Inklusif : Analisis Antar Provinsi Di Indonesia', Buletin Ekonomi Moneter dan Perbankan, Volume 18(No 3), p. 26. Available at: https://www.google.com/url?sa=t\&rct=j\&q=\&esrc=s\&source=web\&cd $=1 \& \mathrm{cad}=$ rja\&uact $=8 \& \mathrm{ved}=2$ ahUKEwjbr4DvyJ_gAhWLto8KHazwBD0QF jAAegQICBAC\&url=https\%3A\%2F\%2Fwww.bi.go.id\%2Fid\%2Fpublika si\%2Fjurnal-

ekonomi\%2FDocuments\%2FInklusi\%2520Keuangan\%2520dan\%252 0Pertumbuhan\%2520Inklusif\%2520Analisis\%2520Antar\%2520Provi nsi\%2520di\%2520Indonesia.pdf\&usg=AOvVaw2NkNdrvtE2jctF68rd9 $\mathrm{X} 44$.

Sarma, M. (2008) 'Index of Financial Inclusion'. Indian Council for Research on International Economic Relations New Delhi. Available at: http://hdl.handle.net/10419/176233.

Sarma, M. (2015) 'Measuring financial inclusion', Economics Bulletin, 35(1), pp. 604-611. 
Equivalence of Islamic Financial Literation Index with...

Setiawati, R. (2015) 'Literasi Keuangan Islam (Suatu Telaah Literatur)', DFEU Jambi.

Singh, U. (2014) 'Financial Literacy and Financial Stability Are Two Aspects of Efficient Economy', Journal of Finance, Accounting and Management, 5(2), p. 59. Available at: https://www.questia.com/library/journal/1P33433185671/financial-literacy-and-financial-stability-are-two (Accessed: 3 February 2019).

Steelyana, E. (2013) 'Perempuan dan Perbankan: Sebuah Tinjauan Tentang Peran Inklusi Keuangan terhadap Pengusaha UMKM Perempuan di Indonesia', The Winners, 14(2), p. 95. doi: 10.21512/tw.v14i2.649.

Umar, A. I. (2017) 'Index of Syariah Financial Inclusion in Indonesia', Buletin Ekonomi Moneter dan Perbankan, 20(1), pp. 99-126. doi: 10.21098/bemp.v20i1.726.

Umar, A. I. (2017) 'INDEX OF SYARIAH FINANCIAL INCLUSION IN INDONESIA', Buletin Ekonomi Moneter dan Perbankan, 20(1), pp. 99126. doi: 10.21098/bemp.v20i1.726.

Worthington, E. L., Jr. et al. (2003) 'The Religious Commitment Inventory--10: Development, refinement, and validation of a brief scale for research and counseling.', Journal of Counseling Psychology, 50(1), pp. 84-96. doi: 10.1037/0022-0167.50.1.84.

Economica: Jurnal Ekonomi Islam - Volume 10, Nomor 2 (2019) 
Miftakhul Khasanah 